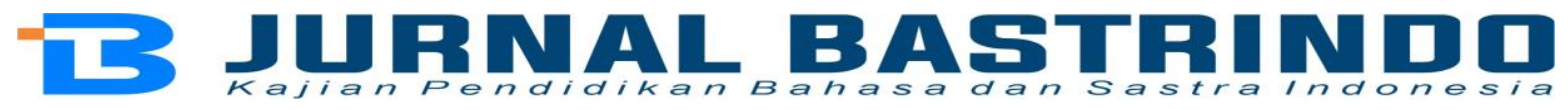

\section{Analisis Formula dalam Novel Kami (Bukan) Sarjana Kertas Karya J. S Khairen: Kajian Formula Sastra Populer}

\author{
Baiq Hikmalia Trisnal; Johan Mahyudi'; ${ }^{2}$ Muh. Khairussibyan ${ }^{3}$ \\ 1,2,3Pendidikan Bahasa dan Sastra Indonesia, FKIP Universitas Mataram
}

\section{Posel: baiq.hikmaliatrisna@gmail.com}

\begin{abstract}
Abstrak: Novel Kami (Bukan) Sarjana Kertas merupakan salah satu novel populer dengan judul yang tampak serius dan belum pernah ada penelitian atas novel tersebut. Belum adanya penelitian atas novel tersebut menginisiasi hadirnya sebuah penelitian yang berjudul Analisis Formula dalam Novel Kami (Bukan) Sarjana Kertas Karya J. S Khairen: Kajian Formula Sastra Populer. Penelitian ini bertujuan menganalisis formula unsur intrinsik yang terdapat dalam novel dan mendeskripsikan bagaimana formula tersebut mempengaruhi popularitas novel Kami (Bukan) Sarjana Kertas. Teori yang digunakan untuk mendukung proses penelitian adalah teori formula. Penelitian ini merupakan penelitian deskriptif kualitatif. Artinya, data-data kualitatif yang telah dikumpulkan melalui studi pustaka dan teknik catat dijabarkan secara deskriptif. Objek penelitian sekaligus yang menjadi sumber data dalam penelitian ini adalah novel Kami (Bukan) Sarjana Kertas. Adapun tahapan analisis data dalam penelitian dilakukan dengan cara membaca novel dengan saksama dan menyeluruh, mencatat hal-hal yang dianggap penting, mengklasifikasikan isi novel berdasarkan formula unsur intrinsik, memberikan penjelasan, dan menarik simpulan. Hasil penelitian menunjukkan bahwa terdapat empat formula unsur intrinsik dalam novel Kami (Bukan) Sarjana Kertas yang menjadikan novel ini digemari oleh para pembaca sehingga termasuk ke dalam jajaran novel best seller di Indonesia. Formula unsur intrinsik tersebut antara lain tema, tokoh/penokohan, latar, dan gaya bahasa. Keempat formula dikemas secara kreatif sehingga tidak membosankan para pembaca ketika menikmati alur cerita yang disuguhkan dalam novel Kami (Bukan) Sarjana Kertas.
\end{abstract}

Kata Kunci: Sastra Populer, Formula, dan Novel.

\section{The Formulas Analysis in Kami (Bukan) Sarjana Kertas Novels by J. S. Khairen: A Study of Popular Literary Formulas}

Abstract:The novel Kami (Bukan) Sarjana Kertas is a popular novel with a little serious looking title and there has never been any research on the novel. The absence of research on the novel has initiated a study entitled Formula Analysis in Novel Kami (Bukan) Sarjana Kertas By J. S Khairen: Study Of Popular Literature Formula. This study aims to analyze the intrinsic element contained in the novel and describe how this formula affects the popularity of the novel Kami (Bukan) Sarjana Kertas. The theory used to support the research process is formula theory. This research is a qualitative descriptive study. This means that qualitative data that has been collected through literature studies and note taking techniques are described descriptively. The object of research as well as the source of data in this research is the novel Kami (Bukan) Sarjana Kertas. The stages of data analysis in research are carried out by read novels carefully and throughly, note things that are considered important, classify novel contents based on the intrinsic element formula, provide explanations, and draw conclusions. The results show that there are four formulas of intrinsic elements in the novel Kami (Bukan) Sarjana Kertas that have made this novel popular with readers so that it is included in the ranks of the best seller novels in Indonesia. The formulas for the intrinsic elements include themes, characters/characterizations, settings, and language styles. The four formulas are packaged creatively so that the readers don't get bored when enjoying the storylines presented in the novel Kami (Bukan) Sarjana Kertas.

Key Words:Popular Literature, Formula, and Novel.

\section{PENDAHULUAN}

Pada awal tahun 2019, seorang penulis muda kelahiran Padang, 23 Januari 1991 yang bernama Jombang Santani Khairen atau yang terkenal dengan nama J. S Khairen 
meluncurkan sebuah novel bergenre fiksi berjudul Kami (Bukan) Sarjana Kertas. Novel ini paradoks sebab merupakan novel populer meskipun judulnya terkesan serius.

Novel ini termasuk salah satu novel populer di Indonesia karena berada dalam jajaran novel best seller. Novel ini terjual lebih dari dua ribu eksemplar dalam kurun waktu kurang dari satu hari. Artinya, novel Kami (Bukan) Sarjana Kertas banyak diminati, terbukti dengan lakunya novel ini di pasaran.

Sastra populer ialah karya sastra yang banyak diminati oleh para pembaca. Hal tersebut karena karya sastra populer bersifat menghibur dan mampu memberikan stimulus positif kepada masyarakat. Sastra populer juga merupakan bacaan ringan yang seringkali memainkan emosi para pembaca dengan rangkaian cerita yang dikemas secara dramatis sehingga banyak orang betah berlama-lama untuk membaca karena mereka penasaran dengan ending cerita bacaan tersebut. Menurut Damono (dalam Dewojati 2015), selain sebagai suatu bacaan yang memiliki banyak penggemar, studi mengenai sastra populer mulai dipandang penting karena dianggap sebagai fenomena dalam sejarah kesusastraan Indonesia modern.

Sebagai sebuah sastra populer, novel Kami (Bukan) Sarjana Kertas terbukti memiliki banyak penggemar. Adanya formula tertentu dalam novel tersebut diasumsikan menjadikan novel ini memiliki banyak penggemar.

Pada dasarnya, formula sama dengan unsur intrinsik yang terdapat dalam sebuah karya sastra. Hanya saja, pengkajian formula lebih mengacu kepada unsur-unsur yang menarik minat para pembaca sehingga sebuah novel menjadi populer. Artinya, para pembacalah yang terlibat dalam menentukan formula-formula yang terkandung di dalam sebuah bacaan. Hal tersebutlah yang menjadi alasan pentingnya penelitian atas unsur formula novel Kami (Bukan) Sarjana Kertas ini yakni di samping untuk mendeskripsikan kecenderungan selera pembaca atas formula cerita, sekaligus juga untuk menggambarkan strategi penceritaan pengarang sehingga pengarang novel ini dan pengarang lainnya bisa berinovasi berdasarkan konvensi formula tersebut.

Berdasarkan uraian di atas, rumusan masalah dalam penelitian ini adalah sebagai berikut: Bagaimanakah formula unsur intrinsik novel Kami (Bukan) Sarjana Kertas karya J. S Khairen sehingga termasuk ke dalam jajaran novel best seller? Adapun tujuan dalam penelitian ini adalah untuk menganalisis formula yang terkandung di dalam novel Kami (Bukan) Sarjana Kertas dan bagaimana cara kerja formula tesebut dalam mempengaruhi popularitas novel Kami (Bukan) Sarjana Kertas karya J. S Khairen.

\section{LANDASAN TEORI}

\section{Sastra Populer}

Populer literature secara harfiah diterjemahkan sebagai sastra populer meskipun banyak orang yang tidak setuju dengan penerjemahan tersebut karena sastra dalam konteks Indonesia merupakan tulisan yang adiluhung sehingga tidak dapat diartikan sebagai literature karena konotasinya yang berbeda. Berkembangnya masyarakat menjadi lebih pragmatis menjadikan kata literatur yang mengacu pada popular literature dapat diterjemahkan dengan mudah menjadi sastra populer (Adi, 2011).

Sastra populer merupakan karya sastra yang dianggap memiliki nilai sastra yang rendah sehingga disebut sebagai karya sastra picisan. Sastra populer dianggap sebagai karya sastra yang diciptakan secara cepat demi memenuhi selera pasar sehingga tidak memperhatikan kadar sastra yang terkandung di dalam karya sastra populer tersebut. Selera pasar itulah yang menjadi target utama para penulis dan penerbit agar karya-karya yang mereka luncurkan laris terjual di pasaran. Dengan demikian, dapat dikatakan bahwa suatu karya novel disebut populer di antaranya karena tema, cara penyajian teknik bahasa, dan penulisannya mengikuti pola umum yang tengah digemari masyarakat pembacanya (Adi: 2011).

\section{Formula}

Penelitian karya sastra secara intrinsik biasanya dilakukan dengan meneliti unsurunsur yang ada pada suatu fiksi, seperti tokoh dan penokohan, alur, struktur alur, latar, dan 
tema. Penelitian genre fiksi populer juga dilakukan dengan melihat unsur-unsur atau elemen suatu fiksi populer. Akan tetapi, berbeda dengan unsur-unsur karya sastra, unsur-unsur dalam konteks fiksi populer disebut sebagai formula. Jadi, secara umum formula dapat disamakan dengan unsur (Adi, 2011).

Menurut Cawelti (dalam Rosyidi, dkk 2010), frasa formula sastra (literary formula) adalah sebuah struktur naratif atau konvensi-konvensi dramatik yang digunakan dalam banyak karya individual. Ia menambahkan dua kegunaan istilah formula yang direlasikan dengan konsepsi yang akan dibuat. Kegunaan petama, sebuah formula adalah secara sederhana menandakan sebuah cara konvensional dalam memperlakukan beberapa hal yang spesifik. Hal yang spesifik merujuk pada pola-pola konvensi spesifik suatu budaya pada periode tertentu dan tidak berarti sama di luar konteks kekhususannya. Kegunaan kedua, istilah formula merujuk pada tipe alur yang lebih besar. Artinya, formula merujuk pada tipetipe alur yang merepresentasikan tipe-tipe cerita, jika tidak universal dalam pesonanya, menjadi populer dalam budaya yang berbeda dan dalam waktu yang berbeda.

Sebuah pola formulaik akan ada untuk sebuah periode waktu yang sesuai untuk dipertimbangkan, sebelum pola dipahami oleh pencipta atau audiensnya sebagai sebuah genre karena konsepsi genre melibatkan sebuah pendekatan estetik untuk struktur sastra. Sebuah formula merupakan semacam pola dalam sebuah cerita. Ketika pembaca sukses mendefinisikan formula, pembaca telah mengisolasi setidaknya satu basis popularitas sejumlah karya. Ketika menjadi formula yang berhasil, sebuah pola cerita secara jelas memiliki ketertarikan dan makna khusus bagi banyak orang dalam budaya (Rosyidi, dkk 2010).

Berdasarkan pemaparan di atas, penelitian formula tidak pernah bisa lepas dari para pembaca sebagai penikmat karya sastra. Keterlibatan para pembaca sangat penting dalam menentukan sebuah formula dalam novel-novel populer. Hal tersebut karena formula sangat tergantung pada selera masyarakat. Secara sederhana, formula merupakan hal-hal yang banyak disukai oleh para pembaca dalam sebuah cerita. Formula juga merupakan hal-hal yang mempengaruhi kepopuleran novel populer sehingga termasuk ke dalam jajaran novel best seller. Alasan novel Kami (Bukan) Sarjana Kertas karya J. S Khairen banyak digemari oleh para pembaca karena novel ini merefleksikan realitas sosial di tengah-tengah masyarakat sehingga pesan moral dan nilai-nilai yang terkandung dalam bacaan dapat dengan mudah terinternalisasi dalam diri para pembaca. Novel ini juga termasuk bacaan ringan yang dikemas dengan bahasa sehari-hari sehingga mudah dipahami dan dijangkau oleh berbagai kalangan. Dengan demikian, penelitian ini difokuskan untuk membahas pola formulaik tema, latar, tokoh/penokohan, dan gaya bahasa yang terdapat dalam novel sehingga menjadikan novel ini populer.

\section{METODE PENELITIAN}

Jenis penelitian yang digunakan untuk menganalisis formula dalam novel (Kami) Bukan Sarjana Kertas adalah penelitian kualitatif. Metodologi kualitatif sebagai suatu prosedur penelitian yang menghasilkan data deskriptif berupa kata-kata tertulis atau lisan dari orang-orang dan perilaku yang dapat diamati (Bogdan dan Taylor dalam Muhammad, 2011).

Sumber data merupakan subjek penelitian dari mana data tersebut diperoleh (Siswantoro, 2005). Sumber data dalam penelitian ini adalah novel Kami (Bukan) Sarjana Kertas karya J. S Khairen yang diterbitkan oleh PT. Bukune Kreatif Cipta dengan jumlah halaman tiga ratus lima puluh tiga. Adapun data dalam penelitian ini adalah data yang berwujud kata-kata, kalimat, dan wacana yang terdapat dalam novel Kami (Bukan) Sarjana Kertas karya J. S Khairen. Menurut Ratna (2007), data dalam penelitian sastra adalah katakata, kalimat, dan wacana. Peneliti memperoleh data dengan membaca serta memahami keseluruhan isi novel Kami (Bukan) Sarjana Kertas. Menurut Zed (2004) studi pustaka merupakan kegiatan yang berkenaan dengan metode pengumpulan data pustaka, membaca, dan mencatat, serta mengolah bahan penelitian. Selain studi pustaka, peneliti juga mengumpulkan data menggunakan teknik catat. Dalam hal ini, peneliti mencatat hasil studi 
dokumen pada metode pengumpulan data sebelumnya. Keraf (1993) menyatakan bahwa sebelum mencatat data, peneliti harus membaca secara instensif terlebih dahulu.

Salah satu instrumen yang digunakan dalam penelitian ini adalah peneliti itu sendiri. Siswantoro (2005) menyatakan bahwa peneliti memiliki peran sentral dalam proses pengumpulan data sehingga tidak dapat melalui perantara atau orang lain. Selain itu, peneliti juga menggunakan tabel sebagai instrumen penelitian.

Metode analisis data dalam penelitian ini adalah metode analisis data deskriptif. Metode analisis data deskriptif merupakan prosedur pemecahan masalah dengan menggambarkan atau melukiskan keadaan subjek atau objek penelitian (seseorang, lembaga, masyarakat, dan lain-lain) pada saat sekarang berdasarkan fakta-fakta yang tampak sebagaimana adanya (Hawari dalam Siswantoro, 2005).

Adapun tahapan analisis data dalam penelitian ini adalah membaca novel dengan seksama dan menyeluruh; mencatat hal-hal yang dianggap penting; mengklasifikasikan isi novel berdasarkan formula unsur intrinsik; memberikan penjelasan; dan menarik simpulan.

Penelitian ini menggunakan metode penyajian analisis data informal dengan cara mendeskripsikan hasil penelitian berupa formula unsur intrinsik yang terdapat dalam novel Kami (Bukan) Sarjana Kertas. Metode penyajian data informal merupakan perumusan dengan menggunakan kata-kata biasa, termasuk juga penggunaan terminologi yang bersifat teknis (Mahsun, 2011).

\section{PEMBAHASAN}

\section{Analisis Formula Unsur Intrinsik Novel Kami (Bukan) Sarjana Kertas Karya J. S Khairen}

1. Tema

Tema merupakan pokok pembicaraan dalam sebuah cerita atau dapat juga berarti pesan yang ingin disampaikan oleh pengarang. Tema biasanya menyajikan nilai yang bersifat universal. Nilai di sini adalah nilai yang bersifat nilai kebajikan manusia. Sebuah karya sastra dapat menghasilkan banyak tema sesuai dengan masalah-masalah di sepanjang cerita. Akan tetapi, tema dalam fiksi populer biasanya lebih sederhana. Masalah ini kemudian didramatisasikan sebagai bahan pokok suatu cerita. Apabila ditinjau dari tema itu sendiri, tema merupakan persoalan yang berhasil menduduki tempat utama dalam cerita (Adi, 2011).

Pengidentifikasian tema dalam fiksi populer dapat diawali dengan cara melihat judul dan gambar sampul. Novel ini berjudul Kami (Bukan) Sarjana Kertas karya J. S Khairen. Judul yang tampak sederhana, tetapi memiliki makna mendalam menjadikan novel ini terkesan tidak biasa-biasa saja sehingga mampu menarik minat para pembaca untuk memahami makna dari judul tersebut secara lebih mendalam dengan cara menikmati alur ceritanya.

Novel Kami (Bukan) Sarjana Kertas bersampul kuning dengan gambar seseorang yang berjalan mengenakan tas selempang, seseorang yang berbahagia mengenakan toga di atas kepala, dan seseorang yang terjatuh di tong sampah. Gambar-gambar yang tertera pada sampul seolah mengisyaratkan rentetan peristiwa yang disuguhkan dalam novel Kami (Bukan) Sarjana Kertas. Hanya dengan melihat gambar yang tertera pada sampul, pembaca sedikit tidak dapat berasumsi bahwa novel ini merepresentasikan realitas sosial yang hidup di tengah-tengah masyarakat, khususnya mahasiswa.

Tema sebagai formula pertama dalam novel Kami (Bukan) Sarjana Kertas dapat dilihat dari kutipan novel. Kutipan novel tersebut antara lain sebagai berikut:

\section{Data 1}

"Masa menghadapi tikus-tikus busuk ini saja kalian tidak bisa. Apalagi menghadapi kejamnya dunia? Nanti setelah kalian lulus, di luar sana, dunia nyata jauh lebih menjijikkan daripada tikus-tikus ini! Mau jadi apa kalian setelah lulus? Sarjana kertas? Ngerasa pintar, hebat di atas kertas, tapi menghadapi dunia nyata malah gak bisa? Kalian ini mahasiswa, bukan mahasisa!"(7)

\section{Data 2}

"Jadi sarjana atau tidak, itu cuma di atas kertas! Banyak orang tak sekolah tinggi tapi sukses. Banyak sarjana, begitu bekerja ternyata tidak bisa apa-apa. Masuk kantor gagah, pulang-pulang gagap. Dunia profesional menuntut begitu tinggi, tak sampai napas mereka berlari. Banyak sarjana tak pandai ilmu hidup, hanya ilmu silabus saja. Sarjana kertas. (123-124) 


\section{Data 3}

"Ijazah bukan jaminan apa-apa. Memang bisa bermanfaat, tapi tak selamanya kertas selembar itu menjadi penentu nasib baik. Dunia berubah, tantangan bertambah, dengkul makin goyah, ah sudahlah. Belajar terus biar tetap bergairah." (233)

Data-data di atas merepresentasikan realitas sosial yang hidup di tengah-tengah masyarakat yang menjadikan para pembaca menyadari bahwa menjadi seorang mahasiswa memiliki tanggung jawab besar untuk diri sendiri dan orang lain sehingga para pembaca sampai pada satu titik di mana mereka akan memahami bahwa menyandang gelar sarjana dan memperoleh ijazah tidak menjamin kehidupan hari ini dan di masa depan akan baikbaik saja, berjalan tanpa rintangan, dan selalu bahagia.

Saat ini, dunia profesional menuntut begitu tinggi. Ijazah tidak selalu menjadi tolok ukur dalam memenangkan pekerjaan. Banyak orang berhasil tanpa mengenyam pendidikan formal. Oleh sebab itu, tujuan utama mengenyam pendidikan di perguruan tinggi atau di manapun, baik formal maupun nonformal, yaitu untuk belajar dan memperoleh ilmu pengetahuan, bukan sekadar memperoleh kertas selembar bernamakan ijazah tersebut. Sejatinya, kuliah adalah untuk meningkatkan kapasitas dan kualitas diri, sebagaimana firman Allah SWT dalam Q.S Al Mujadalah ayat 11 "Allah akan meninggikan orang-orang yang beriman di antaramu dan orang-orang yang diberi ilmu pengetahuan beberapa derajat." Setelah semua tujuan utama tersebut terpenuhi, pada akhirnya kesuksesan tergantung pada nasib, kerja keras, usaha, dan doa.

Melalui kutipan-kutipan novel di atas para pembaca akan dengan mudah mengetahui bahwa novel Kami (Bukan) Sarjana Kertas bertema sosial. Tema sosial meliputi hal-hal yang berada di luar masalah pribadi, salah satunya masalah pendidikan. Kompleksitas dunia mahasiswa tersebut menjadikan novel ini memiliki daya tarik tersendiri untuk menjaring banyak pembaca dari kalangan mahasiswa. Selain itu, realitas sosial tentang sulitnya memperoleh pekerjaan hanya dengan mengandalkan ijazah menjadikan novel ini banyak diminati oleh masyarakat dari berbagai kalangan untuk menelaah isi cerita secara lebih mendalam. Pernyataan-pernyataan itulah yang kemudian menjadi daya tarik tersendiri bagi pembaca untuk memahami keseluruhan isi cerita.

\section{Tokoh/Penokohan}

Kehadiran tokoh, baik tokoh utama ataupun tokoh pendukung memiliki peran penting dalam menghidupkan sebuah cerita, sedangkan penokohan berperan dalam melukiskan citra, karakter, atau sifat tokoh. Dalam sebuah novel, ada yang dinamakan dengan tokoh statis dan tokoh dinamis. Tokoh statis merupakan tokoh yang melukiskan watak tokoh yang tidak berubah sepanjang cerita. Misalnya, seorang tokoh memiliki watak ambisius dari awal sampai dengan akhir cerita. Sebaliknya, tokoh dinamis merupakan tokoh yang melukiskan watak tokoh yang berubah-ubah sepanjang cerita. Misalnya, seorang tokoh memiliki watak pemalas di awal cerita, tetapi setelah melalui getirnya hidup ia berubah menjadi seseorang dengan tekad yang kuat guna memiliki hidup yang lebih baik.

Melalui tokoh cerita inilah pembaca mengikuti alur cerita sehingga secara tidak langsung pembaca ikut merasakan hal-hal yang dialami oleh tokoh-tokoh cerita. Melalui pengenalan watak tokoh cerita, pembaca akan lebih mudah memahami maksud sebuah cerita. Novel Kami (Bukan) Sarjana Kertas menyuguhkan lebih dari satu tokoh utama, yaitu Ogi, Ranjau, Arko, Gala, Juwisa, dan Sania. Keenam tokoh tersebut digambarkan secara lengkap dan utuh dalam novel Kami (Bukan) Sarjana Kertas. Sementara, tokoh-tokoh pendukung yang turut menghidupkan cerita sehingga menarik para pembaca dengan berbagai karakter yang digambarkan sastrawan dalam novel Kami (Bukan) Sarjana Kertas adalah seperti:
a. Catherine (Teman Ogi, Ranjau, Arko, Gala, Juwisa, dan Sania)
b. Bu Lira (Dosen Konseling)
c. Miral (Teman Ogi)
d. Babe Affandi (Ayah Ogi)
e. Emak Zaenab (Ibu Ogi)
f. Mpok Titis (Tante Ogi) 
g. Pak Jaharizal (Dosen Pengantar Ilmu Komunikasi)

h. Sugiono (Dosen Ekonomi)

i. Areng Sukoco (Rektor Kampus UDEL)

j. Gentara Sudjatmiko (Ayah Gala)

k. Ayah Juwisa

1. Nenek Anjali

Tokoh/penokohan sebagai formula kedua dalam novel Kami (Bukan) Sarjana Kertas dapat dilihat dari kutipan novel. Kutipan novel tersebut antara lain sebagai berikut.

\section{DATA 4}

Bagi Ogi, kuliah adalah keterpaksaan, suatu kemunduran mental. Siapa lagi yang memaksa untuk ikut tes dan mendaftar kuliah, kalau bukan sahabatnya si Randi Jauhari alias Ranjau ini. (2)

Kutipan novel dia atas merepresentasikan citra atau karakteristik tokoh Ogi sebagai sosok yang labil atau tidak memiliki prinsip yang kuat dalam hidup sehingga goyah dan membuat dirinya berbuat di luar kemauan sendiri karena terdesak oleh keadaan.

\section{DATA 5}

Sementara bagi Ranjau, kuliah adalah prestasi membanggakan! Ini adalah akhir dari perjuangan beratnya. Perjuangan untuk bisa diterima di UDEL. Yah tak apalah, setahun menganggur dan tes sana-sini, Ranjau akhirnya bisa kuliah juga, meskipun di kampus antah berantah. (2-3)

Kutipan novel di atas merepresentasikan citra atau karakteristik tokoh Ranjau yang memiliki tekad kuat dan gigih dalam mengupayakan sesuatu yang ia inginkan.

\section{Data 6}

"Haha jangan begitu kawan, kuliah itu penting, iya kan, Ranjau? Ah, gue kuliah biar nanti punya masa depan cemerlang! Tentunya sambil berkarya!" Arko menyibakkan rambutnya yang gondrong. (15)

Kutipan novel di atas merepresentasikan citra atau karakteristik tokoh Ranjau yang memiliki optimistis tinggi dalam menyongsong masa depan.

\section{Data 7}

Benar-bener gila mereka bekerja. Bagi Ranjau, jika trio bersama Ogi dan Arko adalah kebinasaan hidup, maka dengan Juwisa dan Gala adalah keluarbiasaan yang dari dulu ia harap-harapkan. Temanteman yang sama ambisiusnya dengan dirinya. (15l)

Kutipan novel di atas merepresentasikan citra atau karakteristik tokoh Gala, Juwisa, dan Ranjau yang memiliki semangat tinggi untuk menggapai mimpi-mimpi mereka.

\section{Data 8}

Memang rumahnya amat sangat sederhana. Berlantai tanah beratap daun kelapa yang dikeringkan. Namun itu tidak membuat Arko, bahkan ibunya, mau begitu saja menerima sesuatu. Selagi kaki masih bisa dilangkahkan, selagi tangan masih bisa menggapai dan menadahkan doa, selagi hati masih keras berupaya, ia tak mau menerima sesuatu cuma-cuma. (244)

Kutipan novel di atas merepresentasikan citra atau karakteristik tokoh Arko dan ibunya yang pekerja keras. Hal tersebut dapat dilihat dari cara Arko dan ibunya dalam menyikapi dan memaknai hidup. Terbukti, mereka tidak pernah mau mengiba dan diberi apapun secara cuma-cuma.

\section{Data 9}

Saat di Amerika, Ogi sudah menyiapkan ini semua. Sebuah hadiah besar. Ogi membeli sebuah rumah untuk Emak Zaenab di dekat pinggiran ibu kota. Kawasan nan asri, tenang dan juga lumayan berkelas.

Untuk ibu dan adik-adiknya, ia beli dari uang keringatnya, dari jerih payahnya. Ia tabung terus, hingga akhirnya bulan lalu terkumpullah sejumlah uang dan Ogi bisa membeli rumah itu dengan uang tunai alias tanpa kredit. (35l)

Kutipan novel di atas merepresentasikan citra atau karakteristik tokoh Ogi yang pada akhirnya menjadi sosok pekerja keras dan bertanggung jawab demi memperoleh kehidupan yang lebih baik dan membahagiakan emak dan adik-adiknya. 
Dengan demikian, data-data di atas menunjukkan tokoh statis dan tokoh dinamis serta citra masing-masing tokoh dalam novel Kami (Bukan) Sarjana Kertas. Pada dasarnya, keenam tokoh (Ogi, Ranjau, Arko, Gala, Juwisa, dan Sania) merupakan tokoh statis jika dilihat dari karakteristik baik hati dan peduli yang ditemukan sepanjang cerita. Tokohtokoh yang konsisten dalam hal kebaikan dan kepedulian tersebut menjadikan pembaca seolah-olah merasakan betapa besar kasih sayang dalam persahabatan mereka hingga dalam situasi paling sulit. Mereka masih setia saling menyemangati untuk terus menghidupkan mimpi-mimpi. Selain dilihat dari karakteristik baik hati dan peduli, tokoh statis dalam novel tersebut juga dapat dilihat dari ambisi dan keseriusan Randi, Arko, Gala, dan Juwisa dalam mengenyam pendidikan demi merealisasikan mimpi-mimpi mereka.

Akan tetapi, beberapa tokoh berubah menjadi dinamis apabila dilihat dari besarnya ambisi mereka dalam menghidupkan mimpi-mimpi. Hal tersebut dapat dilihat dari tokoh Ogi yang awalnya pemalas berubah menjadi sosok pekerja keras hingga menjadi sosok paling sukses di antara kelima sahabatnya. Selain itu, ada Sania yang sebenarnya pintar, tetapi terjerumus dalam pergaulan yang salah hingga mendekam di balik jeruji besi. Pengalaman memang guru terbaik. Setelah ke luar dari penjara, Sania menjadi pribadi yang lebih baik, ia siap mewujudkan mimpi-mimpi yang tertunda, dan membahagiakan kedua orang tua. Keberadaan tokoh dinamis menjadikan sebuah cerita menjadi lebih berwarna hingga mampu menguras emosi para pembaca.

Alasan tokoh-tokoh tersebut dijadikan sebagai tokoh utama adalah karena keenam tokoh mendominasi cerita dalam novel Kami (Bukan) Sarjana Kertas. Perjalanan hidup dan jalinan persahabatan hingga tokoh-tokoh tersebut sukses diceritakan dengan porsi yang sama sehingga keenam tokoh terkesan menjadi sentral atau fokus cerita. Jalinan persahabatan itulah yang lazim ditemukan dalam kehidupan kampus mahasiswa sehingga para pembaca dari kalangan mahasiswa merasa seolah-olah ditarik ke dalam situasi cerita yang terdapat dalam novel Kami (Bukan) Sarjana Kertas.

Tokoh/penokohan berperan besar dalam menghidupkan sebuah cerita dalam novel Kami (Bukan) Sarjana Kertas sehingga pembaca akan senantiasa mengikuti alur cerita guna menemukan nilai yang ingin disampaikan sastrawan melalui tokoh/penokohan yang disuguhkan dalam novel tersebut. Sederhananya, sebuah cerita tidak akan tercipta tanpa adanya tokoh yang berperan di dalamnya.

\section{Latar}

Latar merupakan tempat, waktu, dan suasana ketika terjadinya sebuah cerita. Sebuah cerita haruslah jelas di mana, kapan, dan bagaimana suasana ketika cerita tersebut terjadi. Sastrawan memilih latar dalam sebuah cerita dengan mempertimbangkan unsur watak tokoh-tokohnya dan persoalan atau tema cerita tersebut. Artinya, latar yang digunakan harus sesuai dengan tema cerita.

Dalam novel populer, latar memiliki peran penting sebagai alat untuk menarik perhatian pembaca. Latar juga dapat menentukan jenis cerita itu sendiri. Terdapat tiga latar dalam novel Kami (Bukan) Sarjana Kertas, yaitu latar tempat, latar waktu, dan latar suasana. Latar tempat menyangkut lokasi terjadinya sebuah cerita, latar waktu menyangkut kapan atau waktu terjadinya sebuah cerita, dan latar suasana menyangkut suasana atau keadaan ketika terjadinya sebuah cerita.

Latar sebagai formula ketiga dalam novel Kami (Bukan) Sarjana Kertas dapat dilihat dari kutipan novel. Kutipan novel tersebut antara lain sebagai berikut:

a. Latar Tempat

Latar tempat yang disuguhkan dalam novel Kami (Bukan) Sarjana Kertas adalah sebagai berikut. Latar pertama adalah kampus. Di kampus, para mahasiswa tidak langsung kuliah, tidak pula ospek. Sistem itu sudah dihapus oleh rektor baru. Kedua, kelas konseling yang menggemparkan itu selesai, seluruh mahasiswa berpencar ke jurusan masing-masing. Ketiga, di ruko sempit yang terkempit di antara bangunan kota yang penuh bullshit, tinggallah Babe Affandi dan Emak Zaenab dengan anak-anak mereka yang hidupnya kian hari kian rumit. Keempat, sepeninggal mereka berdua, Ogi memutuskan berpindah ke Tanina Coffe. Tidak butuh waktu lama bagi Ogi untuk menjadikan kafe itu tempat favoritnya karena kecepatan 
wifi yang luar biasa. Kelima, berhari-hari ia lakukan ini, ke kampus UDIN sebagai mahasiswa gelap. Datang bersama Miral ke UDIN, Miral masuk ke kelas, Ogi hanya duduk di pelataran saja. Keenam, Gala berdiri di puncak Rinjani. Ia tatap jauh segara anak sambil bermandikan udara dingin dan selip-selip cahaya matahari pagi. Tak pernah ia menyaksikan sesuatu seperti ini. Ketujuh, sebulan Ogi di Ubud menikmati indahnya hamparan sawah, menghirup udara segar, dan menikmati kicau burung pagi hari sambil mempelajari hal-hal yang tak pernah bisa ia bayangkan. Kedelapan, hari ini, di depan penjara ini, mereka berempat telah berjanji tidak akan membahas kenapa Sania bisa ditangkap. Kesembilan, mereka berhenti di pinggir Kampung Pojok Salak Merah. Sebuah desa yang jauh dari mana-mana, di sekitaran kawasan Jonggol.

Paragraf di atas menyuguhkan tempat-tempat yang dekat dengan kehidupan para pembaca khususnya mahasiswa sehingga menjadikan para pembaca lebih mudah membangun imajinasi mereka terkait kisah yang dituangkan dalam novel Kami (Bukan) Sarjana Kertas. Misalnya, kampus sebagai tempat yang hampir setiap hari dikunjungi oleh mahasiswa, bahkan tidak jarang mahasiswa yang berorganisasi menginap di sana. Selain itu, coffe juga menjadi tren di kalangan mahasiswa sebagai tempat mengerjakan tugas atau sekadar nongkrong dengan teman-teman mereka.

b. Latar Waktu

Latar waktu yang disuguhkan dalam novel Kami (Bukan) Sarjana Kertas. Pertama, setelah makan malam, Zaenab dan Affandi tak tidur melihat uang di tas pinggang yang penuh itu terbaring di pojok kamar mereka. Kedua, tak terasa, dari siang, sore kala matahari mulai rebah, hingga malam hari, Ogi masih saja duduk di Tanina. Ketiga, hingga datanglah senin, UTS hari pertama. Langsung dua mata kuliah diujikan. Keempat, kini, di malam liburan ini, dengan satu jurus jitu, akhirnya Bu Lira berhasil meminta Ogi memberi tahu nama aslinya pada semua temannya. Kelima, tak sadar sudah pukul dua tengah malam. Ranjau dan Gala sudah tak sanggup membuka mata. Keenam, matahari makin tinggi. Gala masih ingin berlama-lama. Setelah merasa cukup, ia turun bersama para porternya. Ketujuh, siang dijemput malam, senja hadir di antaranya. Gala terbangun oleh entakan tipis yang ia tak tahu itu apa.

Paragraf di atas menerangkan waktu dan hari terjadinya sebuah cerita dalam novel Kami (Bukan) Sarjana Kertas. Waktu dan hari tersebut dikemas dengan kreatif dan disandingkan dengan cerita-cerita yang tidak lazim ditemukan dalam novel-novel lain menjadikan novel ini banyak diminati oleh para pembaca. Selain itu, malam hari menjadi waktu paling dominan yang disuguhkan oleh sastrawan. Hal ini sesuai dengan dunia mahasiswa yang identik dengan begadang untuk sesuatu yang bermanfaat atau bahkan tidak bermanfaat sekalipun.

c. Latar Suasana

Latar suasana yang disuguhkan dalam novel Kami (Bukan) Sarjana Kertas. Pertama, "Kamu ke luar dari kelas ini. Sekarang!" Bu Lira, menunjuk Ogi. Suasana kelas jadi canggung. Ogi tak percaya mendengarnya. Kedua, bu Lira melihat ke dalam kelas dengan aman sentosa. Di kelas terdengar suara gaduh yang luar biasa. Suara pekikan, suara ketakutan, suara gempar menggelegar. Ketiga, "Nak." Dengan sangat emosionalBbabe memeluk Ogi. "Akhirnya babe dapet uang buat daftar di kampus itu. Nanti kamu kuliah yang bener ya." Situasi yang agak canggung bagi Ogi. Remasan tangan di pundak Ogi itu perlahan melunak. Keempat, keesokan dan keesokannya lagi, hal yang sama terus terjadi. Ia datang dengan panik dan ketakutan. Lalu menjawab dengan asal-asalan. Kelima, kalang kabut tangis Ogi merobek langit. Histeris betul tangisnya. Sampai suara tangisnya membuat semua orang takut. Malang benar nasib Ogi. Malang yang tak dapat ditolak. Keenam, tak banyak yang bisa disampaikan oleh Nenek Anjali. Begitu juga oleh trio mangap. Mereka hanya mengharu biru. Disaksikan ratusan mahasiswa UDEL lainnya yang sudah bergegas. Ketujuh, deras air mata ibu dan anak itu mengalir. Bukan rumah barunya yang ditangisi Emak Zaenab, tapi banyak hal yang tak terjelaskan, emosi yang meletup-letup dan bercampur menjadi satu. Sudah lama ia tak melihat anak bujangnya. Semua bercampur.

Paragraf di atas menggambarkan suasana terjadinya sebuah cerita. Suasana-suasana tersebut disandingkan sastrawan dengan cerita-cerita yang tidak mudah ditebak bahkan di 
luar imajinasi para pembaca sehingga novel Kami (Bukan) Sarjana Kertas menarik minat banyak orang untuk menikmati alur ceritanya. Selain itu, sastrawan menampakkan karakteristik emosional, panik, dan galau yang umumnya dimiliki oleh mahasiswa. Karakteristik tersebut tidak dapat dihindari karena memiliki korelasi dengan usia dan pencarian jati diri mahasiswa.

Dengan demikian, data-data di atas jelas menunjukkan bahwa secara garis besar novel Kami (Bukan) Sarjana Kertas menonjolkan kota besar dan universitas yang berada di kota tesebut sebagai latar yang dominan menjadi tempat terjadinya sebuah cerita. Kota besar menyuguhkan kontrasnya kehidupan elite dan pinggiran yang jauh dari kata sejahtera seolah-olah merepresentasikan realitas sosial yang terjadi di tengah-tengah masyarakat. Selain itu, universitas menyuguhkan lika-liku kehidupan mahasiswa hingga menuai kesuksesan menyadarkan para pembaca bahwa untuk menjadi "orang" harus melalui terjalnya proses hingga sampai pada kata sukses.

Sastrawan menambahkan latar waktu dalam beberapa bagian cerita untuk memperjelas kapan cerita tersebut terjadi. Seperti waktu dan hari terjadinya. Siang, sore, dan malam hari, begitulah siklus waktu yang disuguhkan dalam novel tersebut. Malam hari menjadi waktu yang dominan disuguhkan oleh sastrawan. Terakhir, sastrawan menambahkan latar suasana yang bertujuan untuk menambahkan efek dramatis dalam cerita. Latar suasana yang disuguhkan sastrawan dalam novel Kami (Bukan) Sarjana Kertas lazim dirasakan oleh pembaca. Seperti perasaan bahagia, sedih, takut, marah, bosan, dan lain sebagainya.

Dunia realitas yang disuguhkan inilah yang menjadi daya tarik tersendiri bagi pembaca untuk menikmati novel Kami (Bukan) Sarjana Kertas. Dunia realitas yang didukung oleh ketiga latar tersebut menarik imajinasi para pembaca sehingga pembaca seolah-olah berada pada situasi yang disuguhkan dalam cerita.

d. Gaya Bahasa

Gaya bahasa merupakan salah satu unsur penting yang tidak dapat diabaikan dalam sebuah cerita karena dapat mendukung keberhasilan meraih pembaca. Dalam novel Kami (Bukan) Sarjana Kertas sastrawan menggunakan bahasa Indonesia tidak baku, bahasa gaul, bahasa Betawi, dan campur kode. Sastrawan menyuguhkan kata-kata yang lazim digunakan dalam kehidupan sehari-hari sehingga mudah dipahami oleh para pembaca. Gaya bahasa sebagai formula keempat dalam novel Kami (Bukan) Sarjana Kertas antara lain sebagai berikut.

Data 10

“What was that?"Ranjau kesal. "Ternyata dalam kopernya itu tikus, Gi! Lo mikir gak sih doi dosen gila! She's a carazy nuts!”(7)

\section{Data 11}

"Iya iya, denger gue denger, bacot banget sih lo kampret! Gak usah pidato. Deh. Kurang-kurangilah." (37)

\section{Data 12}

"Ealah, ngomong apa sih lu benjolan kodok! Tinggal di rumah aye aja dulu ye semua ye?" Melihat wajah Ogi sekeluarga yang sudah hitam kelam, dengan bentuk yang sudah tidak jelas, Mpok Titis justru tak tega. (74) DATA 13

"Haha kita masih ada UAS nanti tiga bulan lagi, bro!" Arko menjelaskan. "Jadi lo mesti banget nih bro, mempertahankan performa lo ini, cie gitu performa. Eh $b t w$ ayolah kita rayakan dengan ngopi-ngopi ganteng." (79)

\section{Data 14}

"Bokap lo meninggal, bukan berarti impian lo juga ikut di kuburkan, kawan." Arko menepuk pundak Ogi. "Gue juga, sama kayak lo. Gue anak yatim. Dari gue ramaja." (86-87)

\section{Data 15}

Pelan-pelan ilmunya dalam bidang komputer bertambah, cakrawalanya makin luas, kemampuannya makin asoy semlohay aduhai. (188) 
Data-data di atas jelas menunjukkan bahwa novel Kami (Bukan) Sarjana Kertas juga didominasi oleh bahasa gaul. Bahasa gaul tersebut dirangkai oleh sastrawan dengan sangat kreatif sehingga terkesan santai dan tidak membosankan ketika dibaca. Saat ini, kehadiran bahasa gaul dianggap wajar karena sesuai dengan tuntutan zaman dan pangsa pasar yang ditujukan oleh sastrawan. Secara umum, bahasa gaul digunakan, dikuasai, dan dipahami oleh masyarakat. Seperti penggunaan kata lo, gue, bokap, dan penggunaan bahasa lainnya ala anak muda masa kini. Penggunaan bahasa gaul tersebut sering ditemukan di kalangan mahasiswa. Selain itu, ada juga penggunaan bahasa Betawi. Bahasa Betawi biasanya digunakan oleh masyarakat Indonesia yang berasal dari suku Betawi. Selain penggunaan bahasa gaul dan bahasa Betawi, sastrawan juga menggunakan bahasa Indonesia yang dipadukan dengan bahasa Inggris atau yang sering disebut dangan campur kode. Campur kode adalah penggunaan satuan bahasa dari satu bahasa ke bahasa lain untuk memperluas gaya bahasa atau ragam bahasa, pemakaian kata, klausa, idiom, sapaan, dan sebagainya. Penggunaan gaya bahasa yang mengikuti perkembangan zaman dan tidak terpaku pada pakem-pakem tata bahasa, tetapi esensi cerita tetap tersampaikan dengan baik menjadikan novel Kami (Bukan) Sarjana Kertas digemari oleh masyarakat.

\section{Formula Best Seller}

Tema merupakan otak dari keseluruhan isi cerita yang disuguhkan dalam novel Kami (Bukan) Sarjana Kertas. Tema tersebut menginisiasi hadirnya tokoh/penokohan dan citra masing-masing tokoh yang digambarkan oleh sastrawan dalam novel Kami (Bukan) Sarjana Kertas. Sama halnya dengan tokoh/penokohan, latar yang disuguhkan dalam novel Kami (Bukan) Sarjana Kertas disesuaikan dengan tema cerita dalam novel tersebut. Terakhir, gaya bahasa yang digunakan dalam novel Kami (Bukan) Sarjana Kertas juga merupakan hasil dari proses penyesuaian terhadap tema.

Dengan demikian, tema dalam novel Kami (Bukan) Sarjana Kertas merupakan formula unsur intrinsik yang paling dominan atau yang menjadi penggerak hadirnya formula unsur intrinsik lainnya, seperti tokoh/penokohan, latar, dan gaya bahasa. Oleh sebab itu, dapat dikatakan bahwa tema merupakan formula best seller yang dimiliki oleh novel Kami (Bukan) Sarjana Kertas. Formula yang menjadikan novel ini banyak diminati oleh para pembaca sehingga termasuk ke dalam jajaran novel best seller di Indonesia.

\section{PENUTUP}

Berdasarkan hasil penelitian yang telah dilakukan terhadap novel Kami (Bukan) Sarjana Kertas karya J. S Khairen, dapat disimpulkan bahwa formula unsur intrinsik pertama yang terdapat dalam novel Kami (Bukan) Sarjana Kertas adalah formula tema. Adapun beberapa cara yang dapat dilakukan oleh pembaca untuk menemukan tema dalam sebuah cerita, yaitu dengan meilihat judul dan gambar sampul. Novel Kami (Bukan) Sarjana Kertas bertema sosial pendidikan, dalam tema tersebut sastrawan mengedepankan bahwa tujuan utama mengenyam pendidikan adalah untuk belajar, memperoleh ilmu pengetahuan, dan meningkatkan kapasitas dan kualitas diri, bukan sekadar memperoleh kertas selembar bernamakan ijazah tersebut. Formula kedua yang terdapat dalam novel Kami (Bukan) Sarjana Kertas adalah formula tokoh/penokohan. Jumlah tokoh/penokohan dalam novel-novel populer biasanya sangat banyak, begitu pula dalam novel Kami (Bukan) Sarjana Kertas. Dalam novel tersebut terdapat delapan belas tokoh yang menghidupkan cerita. Kedelapan belas tokoh tersebut terbagi menjadi tokoh utama dan tokoh pendukung. Tokoh/penokohan yang disuguhkan dalam novel Kami (Bukan) Sarjana Kertas merepresentasikan tokoh statis dan tokoh dinamis dengan citra atau karakteristik tokoh yang labil, ambisius, rajin, malas, mandiri, dan lain sebagainya. Formula ketiga yang terdapat dalam novel Kami (Bukan) Sarjana Kertas adalah formula latar. Formula latar dapat menarik imajinasi para pembaca sehingga para pembaca merasa seolah-olah berada dalam situasi yang disuguhkan dalam cerita. Novel Kami (Bukan) Sarjana Kertas menyuguhkan latar tempat, latar waktu, dan latar suasana. Latar tempat menyuguhkan tempat-tempat yang dekat dengan dunia mahasiswa, seperti kampus, coffe, dan lain sebagainya. Latar waktu yang mendominasi adalah malam hari, hal tersebut sesuai dengan pola kehidupan para pembaca ataupun mahasiswa yang identik dengan begadang untuk sesuatu yang bermanfaat atau bahkan tidak bermanfaat sekalipun. Formula 
latar suasana yang digambarkan dalam novel Kami (Bukan) Sarjana Kertas juga lazim dirasakan oleh para pembaca, seperti perasaan emosional, panik, galau, bahagia, sedih, takut, marah, dan bosan. Formula keempat dalam novel Kami (Bukan) Sarjana Kertas adalah formula gaya bahasa. Formula gaya bahasa yang digunakan adalah bahasa Indonesia tidak baku, bahasa gaul, bahasa Betawi, dan campur kode. Gaya bahasa tersebut lazim digunakan oleh para pembaca dalam kehidupan sehari-hari sehingga mudah untuk dipahami. Penelitian ini dapat dijadikan sebagai referensi dalam pembelajaran sastra populer yang membahas formula unsur intrinsik dalam novel-novel populer. Selain itu, penelitian ini diharapkan dapat menarik minat banyak orang agar lebih serius dalam mengkaji sastra populer karena sampai saat ini jumlah penelitian terhadap sastra populer masih sangat minim.

\section{DAFTAR PUSTAKA}

Adi, I. R. (2011). Fiksi Populer: Teori dan Metode Kajian. Yogyakarta: Pustaka Pelajar.

Anggito, Albi dan Johan Setiawan. (2018). Metodologi Penelitian Kualitatif. https://books.google.co.id/books?hl=id\&elr=\&id=59V8DwAAQBAJ\&oi=fnd\&epg=PPl \&edq=penelitian+kualitatif + menurut + para + ahli $+\&$ cots $=5$ GiBwxixEp\&sig=rSbCcKL5o pfU49flmgDnU5tV6nU\& \&redir esc=y $\# \mathrm{v}=$ onepage\& $\mathrm{q}=$ =penelitian\%20kualitatif\%20me nurut \%20para\%20ahli\&ef=false (Diakses pada 28 Agustus 2020)

Astika, I Made. (2014). Analisis Formula "Diari" Kambing Jantan Karya Raditya Dika. https://ejournal.undiksha.ac.id/index.php/PRASI/article/view/8923/5762 (Diakses pada 31 Agustus 2020)

Dewojati, Cahyaningrum. (2015). Sastra Populer Indonesia. Yogyakarta: Gadjah Mada University Press.

Keraf, Gorys. (1993). Komposisi. Ende Flores, NTT: Nusa Indah.

Mahayana, S Maman. (2009). Kriteria Untuk Menilai Karya Sastra. http://sastraindonesia.com/2009/01/kriteria-untuk-menilai-karya-sastra/ (Diakses pada 19 Oktober 2020)

Mahsun. (2017). Metode Penelitian Bahasa. Depok: Rajawali Pers.

Melati, Baiq Sapita. (2020). “Analisis Formula dalam Novel Finding Srimulat Karya Hilman Hariwijaya : Kajian Sastra Populer" dalam skripsi. Mataram: Universitas Mataram.

Musaddat, Syaiful. (2018). Penelitian Pendidikan Bahasa danSastra Indonesia (BSI). Mataram: Arga Puji.

Ratna, Nyoman Kutha. (2006). Teori, Metode, dan Teknik Penelitian Sastra. Yogyakarta: Pustaka Belajar.

Rosyidi, M. Ikhwan dkk. (2008). Formula dan Eskapisme Dalam Harry Potter : Kajian Satra Formula.http://etd.repository.ugm.ac.id/home/detail pencarian/40363 (Diakses pada 30 Agustus 2020)

Rosyidi, M. Ikhwan dkk. (2010). Analisis Teks Sastra. Yogyakarta: Graha Ilmu.

Semi, Atar. (1990). Metode Penelitian Sastra. Bandung: Angkasa.

Siswantoro. (2005). Metode Penelitian Sastra: Analisis Psikologis. Surakarta: Muhammadiyah University Press.

Suwendra, I Wayan. (2018). Metodologi Penelitian Kualitatif.

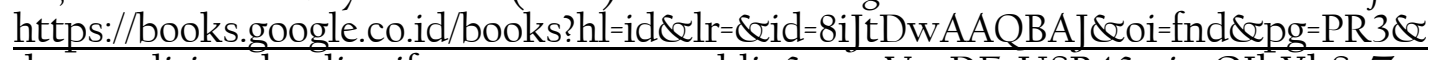
dq=penelitian+kualitatif + menurut + para + ahli $+\&$ ots $=$ VgeDE USB4\& $\$$ sig $=O I k X k S a Z$ WOR3CIm6xRdGkfj2PFg\&redir esc =y $\# \mathrm{v}=$ onepage\& $\mathrm{q}=$ penelitian $\% 20 \mathrm{kualitatif} \% 20$ menurut\%20para\%20ahli\&ef=false (Diakses pada 29 Agustus 2020)

Zed, Mustika. (2004). Metode Penelitian Kepustakaan. Jakarta: Yayasan Obor Indonesia. 